\title{
Metabolism of L-Threonine and its Relationship to Sclerotium Formation in Sclerotium rolfsii
}

\author{
By G. KRITZMAN, Y. OKON, I. CHET AND Y. HENIS \\ Department of Plant Pathology and Microbiology, \\ The Hebrew University of Jerusalem, Rehovot, Israel
}

(Received 22 July 1975; revised 10 November 1975)

\begin{abstract}
SUMMARY
The activities of L-threonine dehydrogenase (I), 2-amino-3-oxybutyrate:CoA ligase (II), malate synthetase (III), isocitrate lyase (IV), glyoxylate dehydrogenase (V), glycine decarboxylase (VI), L-serine hydroxymethyltransferase (VII), glucan synthetase (VIII), glucose 6-phosphate dehydrogenase (IX) and succinic dehydrogenase $(X)$ were detected in cell-free extracts prepared from the mycelium of the fungus Sclerotium rolfsii type R. Transfer of $S$. rolfsii to a threonine-containing medium resulted in a significant increase in the intracellular concentrations of L-threonine, glycine, serine and glyoxylate, and a decrease in oxalate. Incubation with ${ }^{14} \mathrm{C}$-labelled L-threonine resulted in an immediate output of ${ }^{14} \mathrm{CO}_{2}$, and an accumulation of labelled glycine and serine in the mycelium. L-Threonine $\left(\mathrm{IO}^{-2} \mathrm{M}\right)$ increased branching, favoured formation of sclerotia, and induced the formation of enzymes I to VIII, but not IX and X. Sodium oxalate $\left(\mathrm{I} \cdot 5 \times 10^{-2} \mathrm{M}\right)$ inhibited branching, sclerotium formation and the activity of enzymes III and IV. Glycine $\left(\mathrm{IO}^{-1} \mathrm{M}\right)$ inhibited branching, sclerotium formation and activity of $\mathrm{I}$ and II. Ammonium chloride $\left(\mathrm{IO}^{-1}\right.$ to $\mathrm{IO}^{-2} \mathrm{M}$ ) inhibited formation of sclerotia, threonine uptake and activity of III. Acetyl-CoA inhibited V and L-cysteine inhibited I as well as sclerotium formation and branching. It is suggested that hyphal morphogenesis and formation of sclerotia in $S$. rolfsii require an increased supply of carbohydrate intermediates and energy and that these are mainly supplied by the glyoxylate pathway.
\end{abstract}

\section{INTRODUCTION}

The effect of amino acids on morphogenesis has been observed in several fungi, and includes control of lateral hypha frequency in Mucor hiemalis (Plunkett, 1966) and sclerotium formation in Sclerotium rolfsii (Chet, Henis \& Mitchell, I966; Henis, Okon \& Chet, I973). Liu \& Wu (I97I) reported that L-threonine induced sclerotium formation in S. rolfsii, but "made no attempt to explain the mechanism of this effect. The metabolism of L-threonine, given as the sole carbon and nitrogen source, was studied in detail in penicillia and fusaria by Willetts (1972a,b) and by Willetts \& Turner (I97I) who showed that in these fungal groups, L-threonine could be metabolized via the glyoxylate pathway. Although the presence of this metabolic pathway in $S$. rolfsii has been demonstrated (Maxwell \& Bateman, I968a), its role in L-threonine metabolism in this fungus has not yet been studied.

The purpose of this work was to reveal the possible links between the effect of L-threonine on the morphogenesis of $S$. rolfsii and its metabolic pathway in this fungus. 


\section{METHODS}

Strain and growth conditions. Sclerotium rolfsii Sacc. type R ATcc26326 (Chet \& Henis, 1972) was grown at $30^{\circ} \mathrm{C}$ on a cellophane membrane in Petri dishes $(8.5 \mathrm{~cm} \mathrm{diam}$.) containing I $5 \mathrm{ml}$ of synthetic medium (SM) (Okon, Chet \& Henis, 1973). The plates were inoculated in the centre with agar discs $(0.5 \mathrm{~cm}$ diam.) covered with fungal mycelium which had been cut from a 5-day-old colony. The following supplements (AR grade, final concentration) were added separately to the growth medium: L-threonine, $10^{-2} \mathrm{M}$; glycine, $\mathrm{IO}^{-1} \mathrm{M}$; sodium acetate, $0.2 \mathrm{M}$; sodium oxalate, $\mathrm{I} \cdot 5 \times \mathrm{IO}^{-2} \mathrm{M} ; \mathrm{L}$-cysteine, $\mathrm{IO}^{-2} \mathrm{M}^{2} \mathrm{NH}_{4} \mathrm{NO}_{3}$, $0.0 \mathrm{I}$ to $0.02 \mathrm{M} ; \mathrm{NH}_{4} \mathrm{Cl}, 0.0 \mathrm{I}$ to $0.2 \mathrm{M}$; and $\mathrm{NaNO}_{3}, 0.0 \mathrm{I}$ to $0.2 \mathrm{M}$. Ten-fold concentrated solutions of these supplements were sterilized by filtration through a $0.45 \mu \mathrm{m}$ HA Millipore filter and added aseptically to the melted agar.

The effect of these supplements as well as of mitomycin C, DL-p-fluorophenylalanine and cycloheximide (Sigma) on morphogenesis, sclerotium formation and enzyme composition was studied by transferring colonies grown on cellophane from a non-supplemented medium to a supplemented one. No degradation of the cellophane was observed when $S$. rolfsii was grown in the presence of glucose during ro days of incubation.

L-Threonine uptake and transport. The uptake and transport of ${ }_{\mathrm{L}-}\left[{ }^{14} \mathrm{C}\right]$ threonine were studied with cellophane-grown cultures which had been transferred to Petri dishes containing Io $\mathrm{ml}$ liquid medium and $4 \mathrm{~mm}$ glass beads ( 80 per plate) as a support for the cellophane. Labelled threonine (specific activity $10 \mathrm{mCi} \mathrm{mol}^{-1}$ ) was obtained from The Radiochemical Centre (Amersham, Buckinghamshire). The final concentration of the labelled L-threonine in the growth medium was $0.1 \mu \mathrm{Ci} \mathrm{ml}^{-1}$. After incubation, the mycelium was collected from the cellophane, washed with $0 . \mathrm{I}$ M-phosphate buffer $\mathrm{pH} 7.0$ until no radioactivity could be detected in the buffer, dried at $80^{\circ} \mathrm{C}$ for $24 \mathrm{~h}$, weighed and the radioactivity measured in a Packard Tri-Carb scintillation spectrometer model 3003.

Enzyme assays. The mycelium (approx. $3 \mathrm{~g}$ wet $\mathrm{wt}$ ) was homogenized in $3 \mathrm{ml}$ of suitable buffer, using an Ultra-Turrax (Janke \& Kundel K.G., Staufen, West Germany), for I min at $4{ }^{\circ} \mathrm{C}$, and the homogenate was centrifuged at $18000 \mathrm{~g}$ for $20 \mathrm{~min}$ at $4{ }^{\circ} \mathrm{C}$. Unless otherwise stated, low molecular weight compounds were removed from the crude extract by overnight dialysis against distilled water at $4{ }^{\circ} \mathrm{C}$. Protein content of the crude extract was determined with the Folin phenol reagent (Lowry et al., 195I).

The following determinations were made on the crude extract, using the methods indicated. L-threonine dehydrogenase (Willetts \& Turner, 1970); glycine decarboxylase (Willetts \& Turner, 197I); 2-amino-3-oxobutyrate:CoA ligase, malate synthetase, L-serine hydroxymethyltransferase and CoA content (McGilvray \& Morris, I969); isocitrate lyase, glyoxylate dehydrogenase, oxalate and glyoxylate production (Maxwell \& Bateman, 1968b); succinic dehydrogenase (Ulrich \& Mathre, 1972); glucose 6-phosphate dehydrogenase (Caltrider \& Gottlieb, 1963).

Glucan synthetase was determined by a modification of the method of Bartnicki-Garcia \& Lippman (1972) for chitin synthetase. The fungus was homogenized in $0 . \mathrm{I} \mathrm{M}$ tris- $\mathrm{HCl}$ buffer $\mathrm{pH} 7.4$ and the homogenate centrifuged at $27000 \mathrm{~g}$ for $30 \mathrm{~min}$. One $\mathrm{ml}$ of the reaction mixture contained $0 \cdot 14 \mathrm{nmol}$ uridine diphospho[U-14 $\mathrm{C}]$ glucose (specific activity $360 \mathrm{mCi} \mathrm{mol}^{-1}$, The Radiochemical Centre), $0.5 \mu \mathrm{mol} \mathrm{MgCl}_{2}, 0.5 \mu \mathrm{mol}$ cellobiose, and 30 to $400 \mu \mathrm{g}$ protein in $0.25 \mathrm{ml}$ tris buffer. The reaction mixture was incubated for $\mathrm{I} \mathrm{h}$ at $30{ }^{\circ} \mathrm{C}$ in a water bath, and then the reaction was stopped by immersion in boiling water for I min. Samples heated at zero time or lacking the enzyme extract were used as controls. After incubation, the reaction mixture was filtered through a Whatman no. 42 filter paper 
and washed with $100 \mathrm{ml} 0.4 \mathrm{M}-\mathrm{NaOH} / 95 \%(\mathrm{v} / \mathrm{v})$ ethanol $(\mathrm{I}: 7, \mathrm{v} / \mathrm{v})$. The radioactivity remaining on the filter paper was measured and the values were taken as being proportional to enzyme activity; specific activity was expressed as c.p.m. (h incubation) $)^{-1}$ (mg protein) ${ }^{-1}$.

\section{RESULTS}

\section{Effect of $\mathrm{L}$-threonine and sodium oxalate on formation of sclerotia, branching pattern, glyoxylate and oxalate content}

Sclerotium rolfsii type R was grown on cellophane-covered SM for $48 \mathrm{~h}$ and then transferred to Petri dishes containing the test substance(s). Strips of mycelium $(0.5 \mathrm{~cm}$ wide) were collected at intervals from the colony edges, and examined for glyoxylate and oxalate.

When transferred to unsupplemented SM, the fungus covered the plate in $72 \mathrm{~h}$; and the glyoxylate content at the colony margins started to increase on the 5 th day, i.e. two days after the plate was covered with mycelium and sclerotial initials appeared (Fig. I). In addition to the increase in glyoxylate content, a change in hyphal morphology (development of many branches) was seen Io $\mathrm{h}$ after the fungus had been transferred to SM+L-threonine, the average distance (estimated from 25 replicates) between the newly-formed branches (internodes) being $46 \mu \mathrm{m}$, compared with $375 \mu \mathrm{m}$ in the unsupplemented control. A sclerotial circle was formed $48 \mathrm{~h}$ after transferring the mycelium to L-threonine-supplemented medium and production of oxalic acid was significantly inhibited (0.0 $\mathrm{mg} / \mathrm{mg}$ mycelium dry wt compared with $0.19 \mathrm{mg}$ in the SM-grown fungus).

Cultures transferred to media containing sodium oxalate, or L-threonine + sodium oxalate, showed a decrease in glyoxylate content at the colony margins (Fig. I) with a concomitant decrease in branching ( $380 \mu \mathrm{m}$ between internodes) and a total inhibition of sclerotium formation.

\section{$\mathrm{L}-\left[{ }^{14} \mathrm{C}\right]$ threonine uptake}

The uptake of labelled L-threonine by $S$. rolfsii was compared in media containing $0 \cdot I^{\mathbf{M}}$ (on a nitrogen basis), $\mathrm{NH}_{4} \mathrm{Cl}, \mathrm{NH}_{4} \mathrm{NO}_{3}$ or $\mathrm{NaNO}_{3}$ as a nitrogen source. The fungus was grown on cellophane-covered liquid SM for $48 \mathrm{~h}$, transferred to threonine-supplemented medium and incubated for $2 \mathrm{~h}$. Uptake (c.p.m./mg dry wt) was $1 \cdot 97 \times 10^{6}, 2 \cdot 3 \times 10^{6}$ and $4.6 \times \mathrm{IO}^{6}$, respectively, for the above nitrogen sources. Addition of $\mathrm{I} \cdot 0 \mathrm{M}$-sodium oxalate to the medium did not affect uptake. No alteration in $\mathrm{pH}$ was observed after the termination of the experiment.

\section{Effect on enzyme activity of adding supplements to growth media or reaction mixtures}

L-Threonine dehydrogenase. Upon transfer of the fungus to threonine-supplemented SM, the activity of L-threonine dehydrogenase increased sharply and reached its peak after $30 \mathrm{~h}$ concomitantly with the initiation of the first circle of sclerotia (Fig. 2). Addition of sodium oxalate, either to the growth medium at a concentration of $1 \cdot 5 \times 10^{-2} \mathrm{M}$, or to the reaction mixture (Io $\mu \mathrm{mol}$ ) had no effect on the activity (Table 1 ). L-Cysteine and glycine, which inhibit sclerotium formation, strongly inhibited enzyme activity when added either to the medium or to the reaction mixture. Growth on ammonium nitrogen at relatively high concentration $\left(\mathrm{IO}^{-1} \mathrm{M}\right)$ yielded mycelium with a decreased enzyme activity. When added to the reaction mixture, however, $20 \mu \mathrm{mol}$ of ammonium nitrogen had no effect on the activity of $\mathrm{L}$-threonine dehydrogenase.

Aminoacetone synthase and $\mathrm{CoA}$ content. Addition of L-threonine to the growth medium resulted in a Io-fold increase in the activity of aminoacetone synthase (2-amino-3-oxybutyrate: CoA ligase) in the cell-free extract, compared with the activity in a non-supplemented 


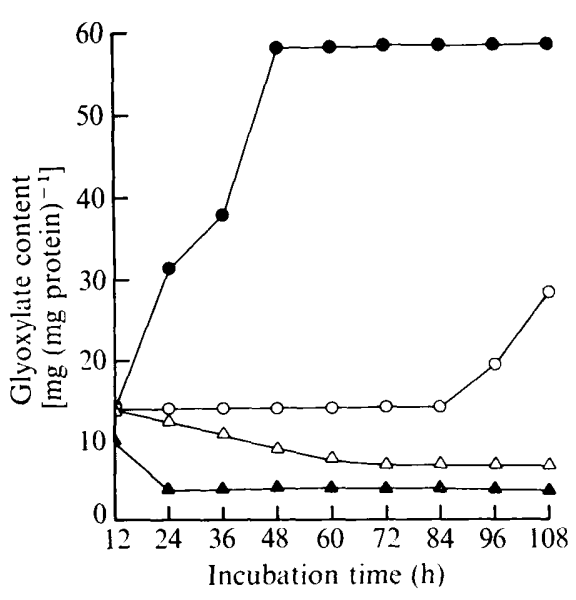

Fig. I

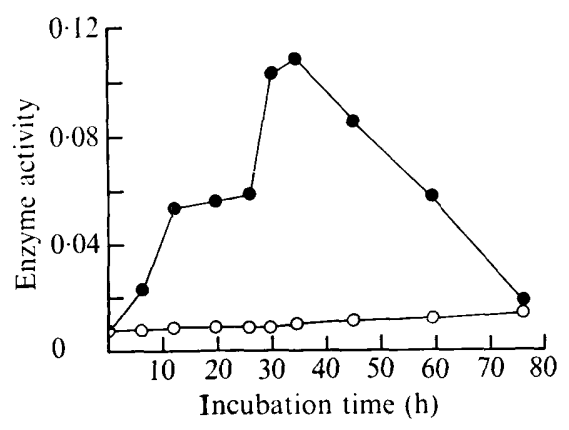

Fig. 2

Fig. I. Effect of L-threonine and sodium oxalate on the glyoxylate content of Sclerotium rolfsii, type R. Mycelium was grown on SM for $48 \mathrm{~h}$ and then transferred to SM (O), SM+ $10 \mathrm{mM}$ L-threonine (O), $\mathrm{SM}+15 \mathrm{mM}$-sodium oxalate $(\triangle)$, or SM + $10 \mathrm{mM}$ L-threonine + 15 mM-sodium oxalate ( $\Delta$ ).

Fig. 2. The activity of $\mathrm{L}$-threonine dehydrogenase extracts prepared from Sclerotium rolfsii, type R. Colonies were transferred after $48 \mathrm{~h}$ growth on SM to SM (O), or to SM+ $10 \mathrm{mM}$ L-threonine (O). Activity is expressed as absorbance at $340 \mathrm{~nm}(\mathrm{mg} \text { protein })^{-1} \mathrm{~min}^{-1}$.

SM (Fig. 3). Glycine, added either to the growth medium or to the reaction mixture, caused a decrease in enzyme activity, whereas oxalate had no effect on either system (Table r).

Except in glycine-grown fungus, which contained $0.036 \mu \mathrm{g} \mathrm{CoA}$ (mg protein) ${ }^{-1}$, mycelium from other treatments contained $0.06 \pm 0.005 \mu \mathrm{g} \mathrm{CoA} \mathrm{(mg} \mathrm{protein)}{ }^{-1}$.

Malate synthetase. The activity of this enzyme was greatly increased when $S$. rolfsii was transferred to threonine-supplemented medium, and decreased on transfer to SM containing ammonium or oxalate. Addition of ammonium ( $20 \mu \mathrm{mol})$ or oxalate ( $10 \mu \mathrm{mol})$ to the reaction mixture also inhibited enzyme activity, whereas threonine or glycine had no effect (Table I). Six hours after the transfer of $S$. rolfsii to $\mathrm{SM}+$ threonine, there was a high level of enzyme activity, but this declined after $20 \mathrm{~h}$ of incubation (Fig. 4). After $85 \mathrm{~h}$, there was a second significant increase in enzyme activity: this preceded the formation of a second sclerotial circle.

Isocitrate lyase. The activity of this enzyme in extracts obtained from threonine-grown $S$. rolfsii did not differ significantly from that of the control, but was higher in extracts of oxalate-grown fungus. On the other hand, the glyoxylate content of the mycelium of fungus grown on SM and SM+threonine was Io-fold higher than that of the oxalategrown culture (Table $\mathrm{I}$ ).

Glyoxylate dehydrogenase. Transfer of $S$. rolfsii to SM+threonine resulted in a sharp decline in the activity of this enzyme in the mycelial extract (Table I and Fig. 5), as did the presence of ammonium chloride in the growth medium. The activity of this enzyme was also adversely affected by the addition of $10^{-5} \mathrm{M}$ acetyl-CoA (Table $\mathrm{I}$ ).

Oxalate production. Transfer of $S$. rolfsii to SM+threonine resulted in a sharp decline in oxalate production (Table I and Fig. 6). However, the presence of ammonium chloride in the growth medium increased the production of oxalate as did the addition of oxalate to L-threonine supplemented medium. 


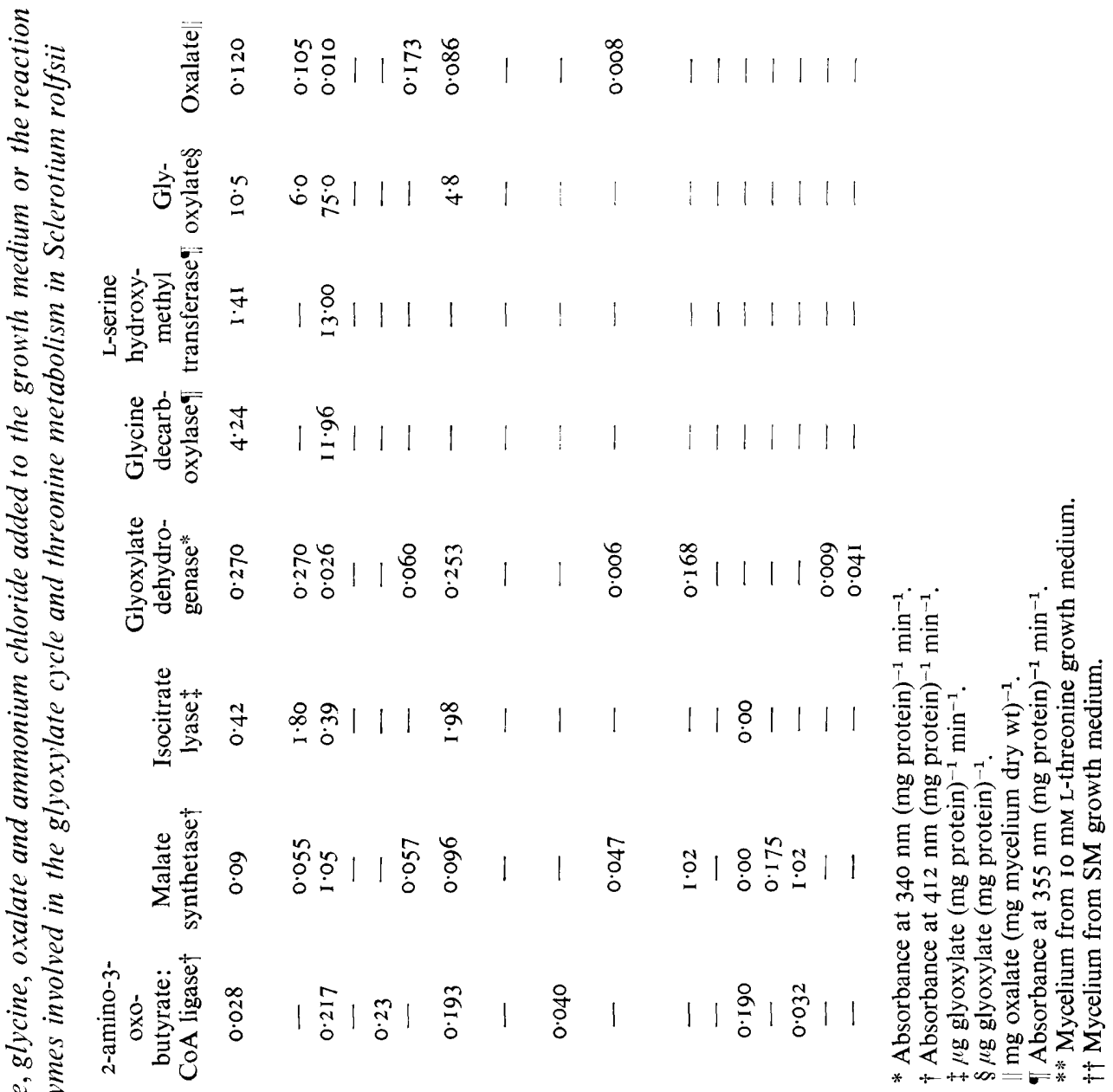

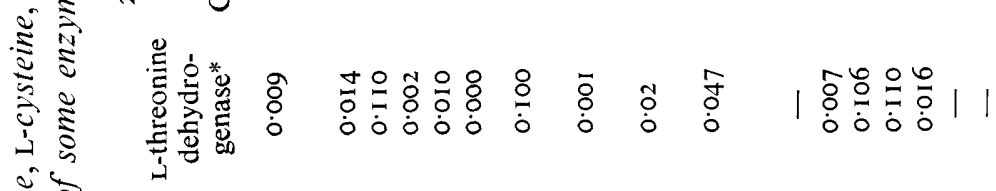

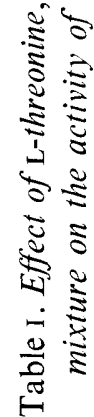

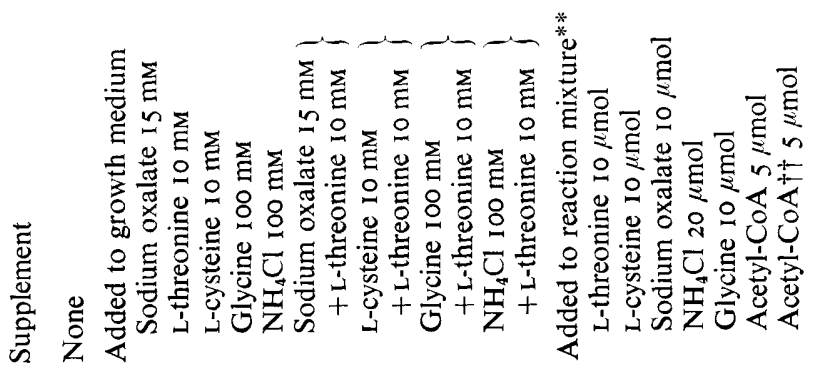




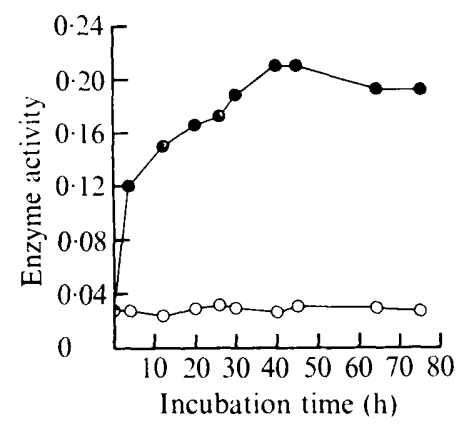

Fig. 3

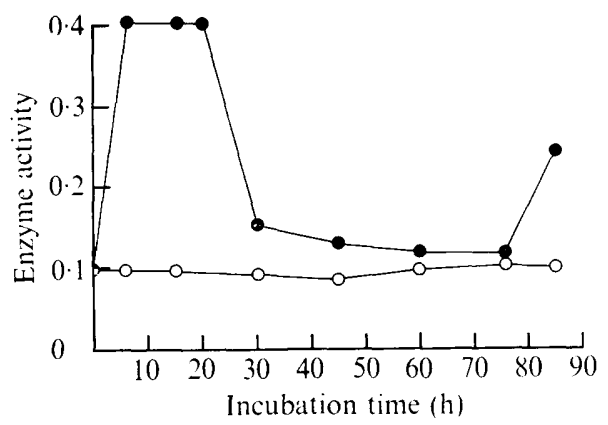

Fig. 4

Fig. 3. The activity of 2-amino-3-oxobutyrate:CoA ligase in extracts prepared from mycelium of Sclerotium rolfsii, type R. Colonies were transferred after $48 \mathrm{~h}$ growth on SM to SM $(\bigcirc)$, or to $\mathrm{SM}+\mathrm{IO} \mathrm{mM}$ L-threonine (O). Activity is expressed as absorbance at $412 \mathrm{~nm}(\mathrm{mg} \text { protein })^{-1} \mathrm{~min}^{-1}$.

Fig. 4. Malate synthetase activity in extracts prepared from mycelium of Sclerotium rolfsii, type $\mathrm{R}$, transferred after $48 \mathrm{~h}$ growth on SM to SM (O), or to SM+10 mM L-threonine (O). Activity is expressed as absorbance at $412 \mathrm{~nm}(\mathrm{mg} \text { protein })^{-1} \mathrm{~min}^{-1}$.

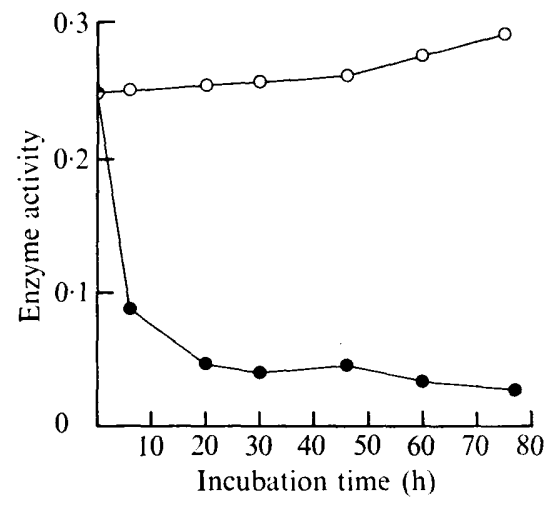

Fig. 5

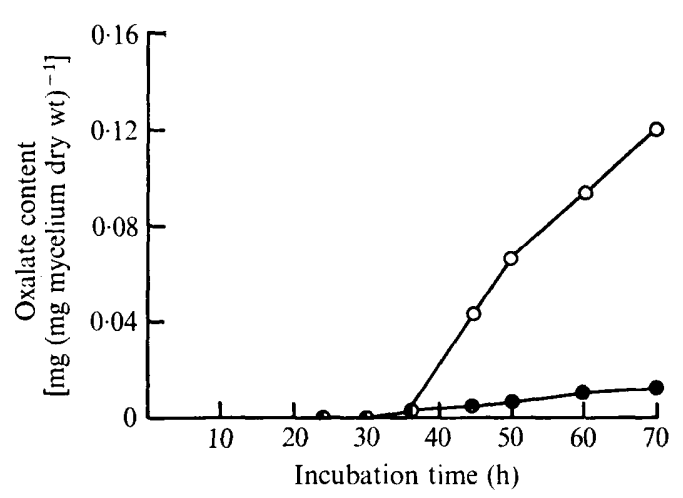

Fig. 6

Fig. 5. Glyoxylate dehydrogenase activity in Sclerotium rolfsii, type R, transferred after $48 \mathrm{~h}$ growth on SM to SM (O), or to SM+10 mM L-threonine (O). Activity is expressed as absorbance at $340 \mathrm{~nm}$ (mg protein) ${ }^{-1} \mathrm{~min}^{-1}$.

Fig. 6. Production of oxalic acid by Sclerotium rolfsii, type R, transferred after $48 \mathrm{~h}$ growth on SM to SM (O), or to SM+ Io mM L-threonine (O).

Glycine decarboxylase and L-serine hydroxymethyltransferase. The activities of these enzymes, which were detected in mycelial extracts of $S$. rolfsii, were much higher when the fungus was grown on SM+threonine rather than SM alone (Table I).

Glucan synthetase. Addition of L-threonine to SM significantly increased enzyme activity [60000 c.p.m. of labelled uridine diphosphoglucose incorporated into glucan compared with 10000 c.p.m. (h incubation) $)^{-1}$ (mg protein) ${ }^{-1}$ in SM-grown fungus] whereas sodium oxalate added to SM or SM + L-threonine caused a significant decrease in glucan synthetase activity $\left.[\mathrm{I} 600 \pm 80 \text { c.p.m. (h incubation })^{-1}(\mathrm{mg} \text { protein })^{-1}\right]$. No inhibition in enzyme activity was obtained when sodium oxalate (I, Io or $100 \mu \mathrm{mol}$ ) was added to the reaction mixture.

Glucose 6-phosphate dehydrogenase and succinic dehydrogenase. No significant differences 
in the specific activities of both glucose 6-phosphate dehydrogenase (50 to 70 units) and succinic dehydrogenase ( 70 to 200 units) were observed in the mycelium when the fungus was grown on either SM, SM+L-threonine, or SM+sodium oxalate media.

\section{Metabolism of L-threonine}

Sclerotium rolfsii was grown on cellophane-covered SM for $48 \mathrm{~h}$, transferred to a medium containing labelled threonine $\left(0 \cdot \mathrm{I} \mu \mathrm{Ci} \mathrm{ml}^{-1}\right)$, and placed in an anaerobic brewer's jar. Carbon dioxide produced during the first $2 \mathrm{~h}$ after transfer, was absorbed on to Whatman filter paper soaked in $4 \mathrm{M}-\mathrm{KOH}$. The filter paper was removed, dried at room temperature and its radioactivity measured by scintillation counter. The rate of $\mathrm{CO}_{2}$ production from $\mathrm{L}$-threonine was influenced by the nitrogen source (O.I M nitrogen basis) present in the medium, being $4 \cdot 60 \times 10^{5}, 2 \cdot 34 \times 10^{5}$ and $\mathrm{I} \cdot 97 \times 10^{5} \mathrm{c}$.p.m. (g mycelium dry wt) ${ }^{-1}$, for $\mathrm{NaNO}_{3}$, $\mathrm{NH}_{4} \mathrm{NO}_{3}$ and $\mathrm{NH}_{4} \mathrm{Cl}$, respectively.

In another experiment, the amounts of L-threonine, L-serine and glycine in the mycelial extract were examined by paper chromatography. Two hours after transfer to a medium supplemented with labelled L-threonine $\left(0 \cdot 2 \mu \mathrm{Ci} \mathrm{ml}^{-1}\right)$, an extract from about $2 \mathrm{mg}$ wet wt of mycelia was spotted on to each paper. After development of the chromatograms, with ninhydrin, the radioactivities of the spots were measured and found to be 66000 c.p.m., 2988 c.p.m. and 1753 c.p.m. for L-threonine, L-serine and glycine, respectively.

\section{DISCUSSION}

Mycelial extracts of threonine-grown Sclerotium rolfsii showed an increased activity of 2-amino-3-oxobutyrate:CoA ligase, glycine decarboxylase and L-serine hydroxymethyltransferase, which operate the glycine-serine pathway. The favourable effect of L-threonine on the glyoxylate cycle could be explained by an increased production of acetyl-CoA and pyruvate, which both contribute to the production of malate, the central metabolite in this pathway. Indeed, the presence of malate synthetase in mycelial extracts of $S$. rolfsii and its increased activity in the threonine-grown fungus has also been demonstrated. The immediate output of ${ }^{14} \mathrm{CO}_{2}$ by $S$. rolfsii in the presence of L-threonine and the prominent accumulation of serine and glycine in the mycelium of the threonine-grown fungus indicate clearly that L-threonine is metabolized in S. rolfsii via the glycine-serine pathway.

The catabolic metabolism of L-threonine in $S$. rolfsii resembles threonine breakdown in Penicillium and Fusarium (Willetts, $1972 a, b$ ). As in $S$. rolfsii, most of the enzymes involved, i.e. L-threonine: NADH dehydrogenase, 2-amino-3-oxobutyrate:CoA ligase, isocitrate lyase and malate synthetase, were induced by L-threonine. However, $S$. rolfsii differs from Penicillium and Fusarium as well as from Arthrobacter (McGilvray \& Morris, 1969) in not being able to utilize L-threonine as a sole source of carbon and nitrogen (unpublished results). Addition of sodium oxalate to the growth medium resulted in a decrease in glyoxylate content of the mycelium and inhibition of sclerotium formation in $S$. rolfsii. Sodium oxalate did not affect L-threonine uptake, but inhibited isocitrate lyase and malate synthetase activities. Oxalate also caused a decrease in branching at the colony margins and reduced glucan synthetase activity without directly inhibiting the enzymic reaction. Thus, L-threonine could favour sclerotium formation by derepression of the enzymes involved in branching and in cell-wall synthesis, brought about by increasing the supply of energy and metabolic precursors, (probably through its inhibitory effect on the production of oxalic acid) followed by increase in the level of acetyl-CoA, which inhibits glyoxylate dehydrogenase activity. 
Induction of conidium formation in Aspergillus (Smith \& Galbraith, 1971) and Neurospora crassa (Turian, 1973) was related to increased activity of the glyoxylate cycle.

In the present study, it was found that L-threonine increased glyoxylate content of the mycelium, branching at the colony margins and formation of sclerotia in $S$. rolfsii. The large quantities of oxalic acid normally produced from glyoxylate by the activity of glyoxylate dehydrogenase (Maxwell \& Bateman, 1968 ) were reduced by the addition of L-threonine to the growth medium.

Presumably, initiation, development and maturation of sclerotia in $S$. rolfsii require higher levels of energy and metabolites than the usual vegetative growth, these requirements being supplied by the glyoxylate cycle. Sclerotium formation is probably inhibited by glucose due to its effect as a catabolic repressor (Lehninger, 1970; Turian, 1973).

Although the glyoxylate cycle seems to play an important role in the morphogenetic processes of $S$. rolfsii, it is apparently not the only factor affecting formation of sclerotia. Similar levels of glyoxylate were observed in $S$. rolfsii types R and A, yet the efficiency of sclerotium formation is higher in type A (Chet \& Henis, 1972).

No significant changes could be observed in the glucose 6-phosphate and succinic dehydrogenase activities upon transfer of $S$. rolfsii to any of the supplemented media, possibly indicating a lesser degree of involvement of the phosphogluconate pathway and tricarboxylic acid cycle in the formation of sclerotia in $S$. rolfsii.

Our results do not allow correlation of isocitrate lyase activity in the intact mycelium with its activity in the mycelial extracts. Sodium oxalate inhibited enzyme activity both in vivo and in vitro and reduced the glyoxylate level in the mycelium, yet the activity (measured in vitro) of isocitrate lyase in oxalate-grown $S$. rolfsiiwas much higher than in the fungus grown on a non-supplemented SM. Possibly, the lower intracellular levels of glyoxylate resulted in depression of isocitrate lyase synthesis. The glyoxylate content of the fungal mycelium is probably a better indicator of isocitrate lyase activity in vivo than enzymic activity in dialysed cell-free extracts.

It seems that formation of sclerotia in S. rolfsii, the catabolic metabolism of L-threonine, and the metabolic pathways involved, are controlled at the levels both of enzyme synthesis and activity.

\section{REFERENCES}

BARTNICKI-GARCIA, S. \& Lippman, E. (I972). Inhibition of Mucor rouxii by polyoxin D: effects of chitin synthetase and morphological development. Journal of General Microbiology 7r, 30I-309.

Caltrider, P. G. \& GotTlieb, D. (1963). Respiratory activity of enzyme for glucose catabolism in fungus spores. Phytopathology 53, $102 \mathrm{I}-1030$.

Chet, I., Henis, Y. \& Mrtchell, R. (1966). The morphogenetic effect of sulphur-containing amino acids, glutathione and iodoacetic acid on Sclerotium rolfsii. Journal of General Microbiology 45, 54 I-546.

CHET, I. \& HENIS, Y. (1972). The response of two types of Sclerotium rolfsii to factors affecting sclerotium formation. Journal of General Microbiology 73, 483-486.

Henis, Y., OKon, Y. \& CHET, I. (1973). The relationship between early hyphal branching and formation of sclerotia in Sclerotium rolfsii. Journal of General Microbiology 79, $147^{-1} 50$.

LeHNinger, A. (1970). Biochemistry. New York: Worth.

LIU, M. F. \& WU, L. C. (1971). The effect of amino acids on the growth and morphogenesis of Sclerotium rolfsii Sacc. Plant Protection Bulletin, Taiwan 13, 87-96.

Lowry, O. H., Rosebrough, N. J., FARr, A. L. \& Randall, R. J. (I95I). Protein measurement with the Folin phenol reagent. Journal of Biological Chemistry 193, 265-275.

Maxwell, D. P. \& Bateman, D. F. (1968a). Glucose catabolism in Sclerotium rolfsii. Phytopathology 58, $1630-1634$.

Maxwell, D. P. \& Bateman, D. F. (1968 b). Oxalic acid biosynthesis by Sclerotium rolfsii. Phytopathology 58, I635-1642.

McGilvray, D. \& Morris, J. G. (I969). Utilization of L-threonine by a species of Arthrobacter. Biochemical Journal 112, 657-67I. 
OKon, Y., Chet, I. \& Henis, Y. (I973). Effect of lactose, ethanol and cycloheximide on the translocation pattern of radioactive compounds and sclerotium formation in Sclerotium rolfsii. Journal of General Microbiology 74, 25I-258.

Plunkett, B. E. (I966). Morphogenesis in the mycelium: control of lateral hypha frequency in Mucor hiemalis by amino-acids. Annals of Botany 30, 133-150.

Smith, J. E. \& Galbraith, J. C. (I97I). Biochemical and physiological aspects of differentiation in the fungi. Advances in Microbial Physiology 5, 45-134.

Turian, G. (1973). Induction of conidium formation in Neurospora by lifting of catabolite repression. Journal of General Microbiology 79, 347-350.

Ulrich, J. T. \& MAThre, D. E. (I972). Mode of action of oxathiin systemic fungicides. V. Effect on electron transport system of Ustilago maydis and Saccharomyces cerevisiae. Journal of Bacteriology IIo, 628-632.

Willetts, A. J. (1972a). Metabolism of threonine by penicillia: growth on threonine as a sole carbon and nitrogen source. Journal of General Microbiology 73, 7I-78.

WILleTtS, A. J. (I972 $b$ ). Metabolism of threonine by fusaria: growth on threonine as the sole carbon and nitrogen source. Antonie van Leeuwenhoek 38, 59 I-603.

Willetts, A. J. \& Turner, J. M. (I970). Threonine metabolism in a strain of Bacillus subtilis. Biochemical Journal II7, 27P-28P.

Willetts, A. J. \& Turner, J. M. (197I). L-threonine acetaldehyde lyase in a strain of Bacillus subtilis. Biochimica et biophysica acta 252, $105-110$. 